\title{
ДОСЛІДЖЕННЯ ВПЛИВУ ФІЗИЧНОГО НАВАНТАЖЕННЯ ТА СТРЕСУ НА СТАН ЩИТОПОДІБНОЇ ЗАЛОЗИ ПРИ ГІПОТИРЕОЗІ
}

\author{
Н.Г. Побігун
}

\author{
Івано-Франківський начіональний медичний університет, кафедра фізіології, \\ м. Івано-Франківськ, Україна, \\ ORCID ID: 0000-0001-8367-3419, e-mail: nadiia.pobigun@ukr.net
}

Резюме. Мета: вивчення впливу хронічного емоційно-больового стресу (ХC) та помірного фізичного навантаження (ПФН) на зміни морфофункціонального стану щитоподібної залози (Щз) при гіпотиреозі (Г).

Матеріали та методи. Дослідження провели на 48-ми статевозрілих щурах-самцях, які були розділені на чотири групи: 1-ша - інтактні тварини; 2-га - тварини з Г; 3-тя - тварини, які піддавались дії ХС та ПФН; 4та - тварини з Г за умов ХС та ПФН. Г моделювали додаванням до питної води мерказолілу протягом 15 днів. ХС моделювали по 1 год протягом 30 днів. ПФН моделювали бігом у тредбані упродовж 30 днів. У плазмі крові визначали вміст тиреотропного гормону (ТТГ), трийодтироніну (вТ3), тироксину (вТ4) та розраховували показник тиреоїдного індексу (ТI). Морфологічний стан ЩЗ вивчали за допомогою мікроскопії. Статистичний аналіз отриманих результатів здійснювали з використанням t-критерію Стьюдента. Відмінності вважали статистично вірогідними при $\mathrm{p}<0,05$.

Результати дослідження. Поєднаний вплив ХС і ПФН не призвів до вірогідних змін вмісту ТТГ та йодовмісних гормонів ЩЗ відносно результатів інтактних тварин. Дані мікроскопічного дослідження ЩЗ підтверджують біохімічні зміни і свідчать про відсутність негативної дії ХС на показники тиреоїдного профілю при ПФН. Проте імуноферментний аналіз плазми крові та мікроскопічне дослідження ЩЗ тварин з дефіцитом тиреоїдних гормонів за умов ХС та ПФН виявили значне погіршення показників гіпофізарно-тиреоїдного статусу відносно даних гіпотиреоїдних щурів.

Висновки. ПФН здійснює позитивний вплив на структурно-функціональний стан ЩЗ при дії ХС, але такий ефект відсутній за умов гіпотиреозу.

Ключові слова: хронічний стрес, фізичне навантаження, гіпотиреоз, тиреоїдні гормони, морфологія щитоподібної залози.

Вступ. Гормони щитоподібної залози (ЩЗ) приймають безпосередню участь у регуляції практично всіх видів метаболічних процесів та вісцеральних систем організму. Нормальний рівень тиреоїдних гормонів є неодмінною частиною адаптивних реакцій, які відбуваються у відповідь на будь-яке інтенсивне навантаження. Тому навіть найменший дефіцит йодовмісних гормонів ЩЗ призводить до змін в роботі не тільки ендокринної системи, а й організму в цілому, спричиняючи суттєві, іноді незворотні порушення.

Сучасні умови життя призводять до зростання стресорного навантаження. Хронічний стрес викликає виснаження функціональних резервів, порушення адаптаційних можливостей організму, індукування маніфестних станів. Тому дослідження останніх років направлені на пошук механізмів підвищення адаптації організму та шляхів протистояння стресу, серед яких чільне місце займають регулярні дозовані фізичні навантаження помірної інтенсивності.

Обгрунтування дослідження. У ході наукових досліджень функціонального стану ЩЗ при дії стресу встановлено протилежні зміни рівня тиреоїдних гормонів, що можна пояснити впливом різних за природою та тривалістю стресорних факторів. У відповідь на гострий стрес відбувається мобілізація організму, зумовлена підвищенням вмісту тиреоїдних гормонів поряд із катехоламінами та кортикостероїдами [1]. Тривала дія стрес-факторів спричиняе зниження секреторної функції Щ3 $[2,3,4]$. Отже, в умовах стресу ЩЗ піддається активації з поступовим виснаженням при тривалому впливі стресогенного чинника. На думку багатьох науковців, фізичні тренування можна розглядати як засіб попередження захворюваності та покращення функцій організму, оскільки вони викликають адаптаційні зміни, які ведуть до підвищення працездатності [5]. Регулярне фізичне навантаження помірної інтенсивності підвищує резистентність організму до впливу стресфакторів [6]. Слід зазначити, що зміни функції ЩЗ залежать від тривалості та інтенсивності навантаження. Незважаючи на велику кількість робіт, присвячених вивченню впливу тривалої дії стресу та фізичних тренувань, їх поєднаний вплив на стан ЩЗ не вивчався.

Мета дослідження: вивчення поєднаного впливу хронічного емоційно-больового стресу (ХC) та помірного фізичного навантаження (ПФН) на зміни морфофункціонального стану ЩЗ при гіпотиpeoзi (Г).

Матеріали та методи. Усі піддослідні тварини утримувались при звичайному світловому й температурному режимах в ідентичних умовах віварію кафедри фізіології Івано-Франківського національного медичного університету. Щури пере- 
бували на стандартному харчовому раціоні з вільним доступом до їжі та води. Усі експерименти проведені відповідно до положень “Директиви Європейського парламенту та Ради ЄС 2010/63/СС від 22.09.2010 р. про захист тварин, які використовуються для наукових цілей” [7], Закону України №3447-IV від 21.02.2006p. "Про захист тварин від жорстокого поводження", згідно з вимогами комісії з біоетики Івано-Франківського національного медичного університету. Дослідження провели на 48-ми білих лабораторних статевозрілих щурах-самцях, які були розділені на чотири групи: 1-ша $(\mathrm{n}=12)$ - інтактні тварини; 2-га (n=12) - тварини з Г; 3-тя $(\mathrm{n}=12)$ - тварини, які піддавались дії ХC та ПФН; 4-та (n=12) тварини з Г за умов впливу ХС та ПФН. Г моделювали згідно з методикою М. В. Небожиної щоденним додаванням до питної води тварин мерказолілу (ТОВ “Здоров’я”, м. Харків, Україна), який є синтетичним препаратом 3 тиреостатичною дією, зумовленою інгібуванням активності пероксидази [8]. Доза становила 10 мг/кг маси тіла тварини протягом 15 днів та 5 мг/кг маси тіла до завершення експерименту. ХС моделювали згідно з методикою О. Desiderato в модифікації С. Д. Валова щоденно по 1 год протягом 30 днів, що викликало формування стресорної реакції у тварин, зумовленої як наявністю конфлікту між виробленням умовного рефлексу уникнення та безумовним больовим подразником, так i постійною напругою в очікуванні електро-больової дії [9]. Для моделювання ПФН щури щоденно бігали по 15 хв у широкострічковому тредбані з постійною швидкістю руху стрічки $20 \mathrm{M} /$ хв упродовж 30 днів [10]. Швидкість бігу 20-25 м/хв для білих щурів вважається помірною та становить приблизно 40-50\% від максимальної інтенсивності. Евтаназію тварин здійснювали шляхом внутрішньоочеревинного введення кетаміну 3 розрахунку $100 \mathrm{Mг} /$ кг маси тіла тварини. Забір крові проводили з черевної аорти. Гепарин використовували у якості антикоагулянта. Кров центрифугували 15хв 3 швидкістю 3000об/хв. Функціональну активність ЩЗ оцінювали шляхом визначення у плазмі крові концентрації тиреотропного гормону аденогіпофіза (ТТГ), вільного трийодтироніну (вТ3), вільного тироксину (вТ4) відповідно до інструкцій стандартних тест-систем (ТОВ "Гранум" м. Харків, Україна) та розрахунку показника тиреоїдного індексу (TI) за формулою ТI=(вT3+вТ4)/TТГ. Для проведення світлооптичної мікроскопії забирали шматочки Щ3, які забарвлювали гематоксиліном та еозином відповідно до загальноприйнятих методик. При електронній мікроскопії ультратонкі зрізи ЩЗ вивчали під електронним мікроскопом 3 подальшим фотографуванням при збільшенні від 4800 до 16000 разів. Перевірку нормальності розподілу даних проводили за методом Колгоморова-Смірнова та Ліліфорса. Статистичний аналіз отриманих результатів здійснювали з використанням t-критерію Стьюдента 3 поправкою Бонферроні-Холма в програмі Statistica 6.0 [11]. Дані представлені у вигляді $\mathrm{M} \pm \sigma$, де $\mathrm{M}-$ середне значення, $\sigma$ - стандартне відхилення. Відмінності вважали статистично вірогідними при $\mathrm{p}<0,05$.

Результати дослідження. У попередньому нашому дослідженні [12] в сироватці крові щурів з Г спостерігали достовірне підвищення рівня ТТГ, зменшення вмісту вТ3, вТ4 та величини ТІ. При проведенні світлооптичної мікроскопії ЩЗ тварин із дефіцитом тиреоїдних гормонів було зафіксовано різного розміру фолікули, здебільшого неправильної форми, перерозтягнені колоїдом, плоский фолікулярний епітелій, проліферацію епітелію міжфолікулярних острівців, розширені за рахунок набряку сполучнотканинні прошарки, підвищену інтенсивність кровопостачання залози. Субмікроскопічно було виявлено потовщення базальної мембрани, вкорочені та нечисленні мікроворсинки, розширені канальці й цистерни гранулярної ендоплазматичної сітки, мітохондрії 3 дезорганізованими кристами і просвітленим матриксом. У плазмі крові щурів, які знаходились за умов поєднаної дії ХС та ПФН достовірних змін показників функціональної активності гіпофізарно-тиреоїдної системи, зокрема рівня ТТГ, вТ3, вТ4 та величини ТI, відносно даних контрольної групи не виявлено (табл.1).

Під час мікроскопічного дослідження ЩЗ тварин, які зазнавали поєднаного впливу довготривалого стресу очікування та фізичного навантаження помірної інтенсивності, виявлено переважання в гістоструктурі залози невеликих i середніх за розміром фолікулів, епітелій яких кубічний, а подекуди й циліндричний (рис. 1).

Добре візуалізуються округлої форми ядра тироцитів. В усіх полях зору спостерігається утворення нових фолікулів. Біля апікального полюса тироцитів багато дрібних вакуолей резорбції, які місцями зливаються у просвітлені смужки. Міжфолікулярні сполучнотканинні прошарки малопомітні, проте добре виражене судинне оточення (рис. 2).

Таблиця 1

\begin{tabular}{|c|c|c|c|c|c|}
\hline Показники & $\begin{array}{l}1 \text { група } \\
\text { (інтактні) }\end{array}$ & $\begin{array}{l}2 \text { група } \\
(\Gamma)\end{array}$ & $\begin{array}{l}3 \text { група } \\
(\mathrm{XC}+\Pi \Phi H)\end{array}$ & $\begin{array}{l}4 \text { група } \\
(\Gamma+X C+\Pi \Phi Н)\end{array}$ & Значення Р \\
\hline $\begin{array}{l}\text { ТТГ, } \\
\text { мМО/мл }\end{array}$ & $0,02 \pm 0,01$ & $0,05 \pm 0,01$ & $0,02 \pm 0,01$ & $0,12 \pm 0,04$ & $\begin{array}{l}\mathrm{p}_{1-3}>0,05 \\
\mathrm{p}_{2-4}<0,001\end{array}$ \\
\hline $\begin{array}{l}\text { в }_{3}, \\
\text { пмоль/л }\end{array}$ & $5,57 \pm 0,91$ & $2,7 \pm 1,08$ & $5,17 \pm 0,62$ & $1,67 \pm 0,21$ & $\begin{array}{l}\mathrm{p}_{1-3}>0,05 \\
\mathrm{p}_{2-4}<0,05\end{array}$ \\
\hline $\begin{array}{l}\text { в } 4, \\
\text { ПмОль/л }\end{array}$ & $10,35 \pm 2,14$ & $3,57 \pm 1,05$ & $12,14 \pm 3,28$ & $1,32 \pm 0,18$ & $\begin{array}{l}\mathrm{p}_{1-3}>0,05 \\
\mathrm{p}_{2-4}<0,001\end{array}$ \\
\hline $\mathrm{TI}$ & $\begin{array}{l}1009,7 \\
\pm 553,67\end{array}$ & $\begin{array}{l}122,08 \\
\pm 31,94\end{array}$ & $\begin{array}{l}1060,68 \\
\pm 389,28\end{array}$ & $27,08 \pm 10,34$ & $\begin{array}{l}\mathrm{p}_{1-3}>0,05 \\
\mathrm{p}_{2-4}<0,001\end{array}$ \\
\hline
\end{tabular}




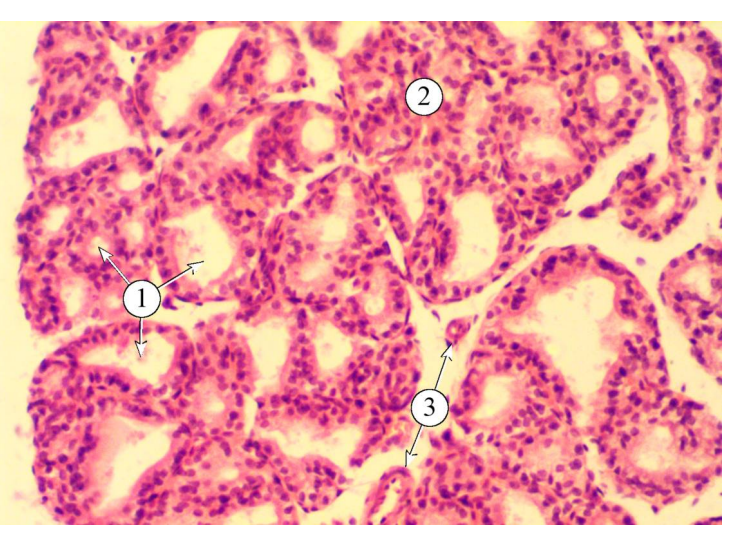

Рис. 1. Гістоструктура щитоподібної залози щура за умов дії стресу та фізичного навантаження. 1 - різнокаліберні фолікули, 2 міжфолікулярні острівці, 3 - кровоносні судини. Забарвлення: гематоксилін і еозин. Зб.: × 200.

На фоні дії мерказолілу поєднаний вплив довготривалого стресу очікування та фізичних навантажень помірної інтенсивності призвів до більш вираженого погіршення тиреоїдного профілю (табл. 1), а саме: достовірного зростання в плазмі крові рівня ТТГ (у 2,4 рази, $<<0,001$ ), зменшення вмісту вТ3 (в 1,6 рази, $\mathrm{p}<0,05)$, вТ4 (у 2,7 рази, $\mathrm{p}<0,001)$ та показника ТІ (в 4,5 рази, $<<0,001)$ відносно даних тварин із зниженою функцією ЩЗ.

За представлених експериментальних умов у результаті світлооптичного дослідження в гістоструктурі ЩЗ виявлено острівці із десквамованими тироцитами та десквамацію епітелію в просвіт фолікула серед невеликої кількості збережених фолікулів, що відповідає колоїдно-десквамативному типу будови (рис. 3). У порожнині фолікулів біля апікального полюса тироцитів знаходиться розріджений блідого кольору колоїд. Епітелій більшої частини фолікулів

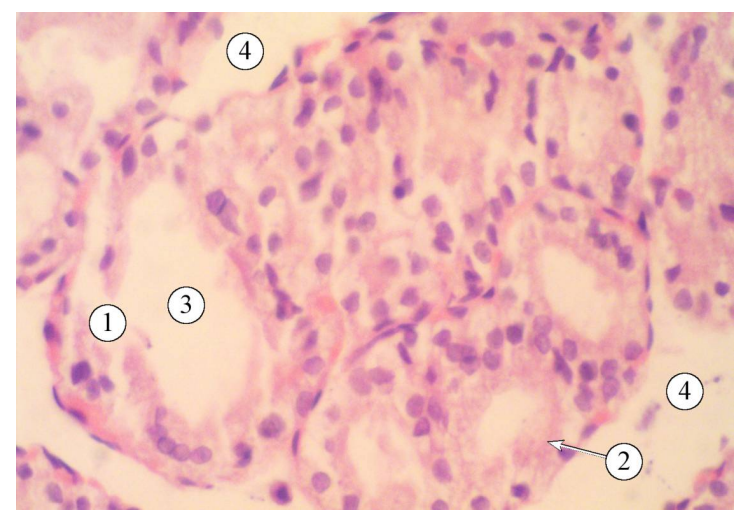

Рис. 3. Гістоструктура щитоподібної залози щура 3 гіпотиреозом в умовах посднаного впливу хронічного стресу та фізичного навантаження. 1 десквамовані тироцити, 2 - апікальний полюс тироцитів, 3 - колоїд, 4 - міжчасточкові сполучнотканинні прошарки. Забарвлення: гематоксилін і еозин. 3б.: × 400.

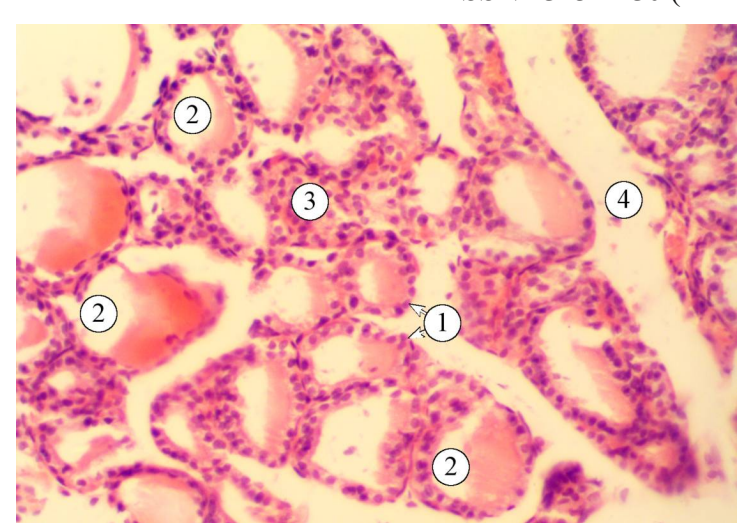

Рис. 2. Гістоструктура щитоподібної залози щура, який знаходився за умов впливу фізичного навантаження та хронічного стресу. 1 - тироцити на базальній мембрані, 2 - вакуолі резорбції, 3 міжфолікулярні острівці, 4 - міжчасточкові сполучнотканинні прошарки. Забарвлення: гематоксилін і еозин. 3б.: × 200.

плоский. У цитоплазмі епітеліоцитів спостерігаються множинні вакуолі резорбції, ядра еліпсоподібної форми, слабобазофільні. Помітні колабовані фолікули. Міжфолікулярні сполучнотканинні прошарки розширені за рахунок вираженого набряку у судинностромальному компоненті залози.

При електронно-мікроскопічному дослідженні Щ3 тварин з Г, які піддавались тривалій дії стресорів та фізичному навантаженню помірної інтенсивності, виявлено таку ж тенденцію (рис. 4). Інвагінації нуклеолеми, під якою сконденсовані грудочки хроматину, спричиняють деформацію ядра тироцита. Органели деформовані, хаотично розміщені. Спостерігаються нечисленні, вакуолізовані з різко просвітленим матриксом та дезорганізованими i зруйнованими кристами мітохондрії. Контакти між сусідніми тироцитами та з базальною мембраною порушені, що веде до десквамації.

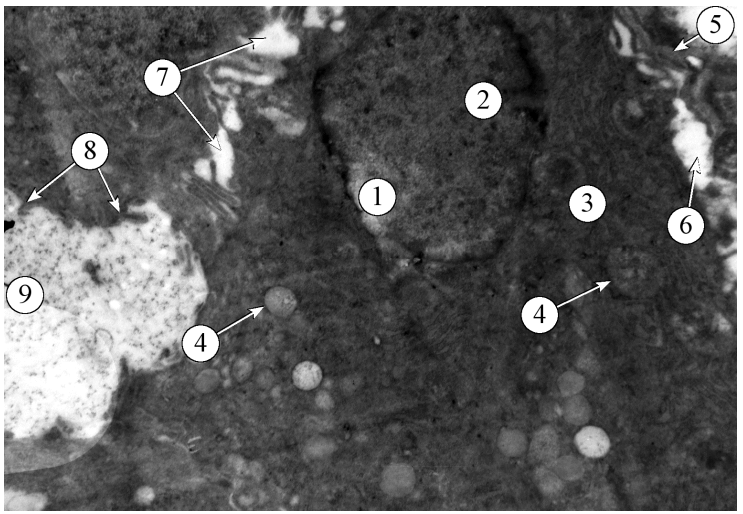

Рис. 4. Фрагмент фолікула щитоподібної залози щура 3 гіпотиреозом за умов стресу та фізичного навантаження. 1 - ядро тироцита, 2 інвагінація нуклеолеми, 3 - гранулярна ендоплазматична сітка, 4 - мітохондріі, 5 - базальна мембрана, 6 - десквамація тироцита, 7 - порушені контакти між тироцитами, 8 - мікроворсинки, 9 колоїд. Зб. 6400. 
Обговорення результатів. У щурів, які зазнавали поєднаного впливу $\mathrm{XC}$ та ПФН, не встановлено вірогідних змін вмісту ТТГ та йодовмісних гормонів ЩЗ у плазмі крові відносно результатів інтактних тварин. Дані мікроскопічного дослідження ЩЗ щурів, які знаходились за вказаних умов, підтверджують біохімічні зміни і свідчать про відсутність негативної дії тривалого стресу очікування на показники тиреоїдного профілю за умов фізичних навантажень помірної інтенсивності. Такі ж результати присутні в роботах інших науковців, які вказують на підвищення резистентності організму до стресорних чинників при регулярних ПФН $[6,13]$. Проте імуноферментний аналіз плазми крові, світлооптичне та електронно-мікроскопічне дослідження ЩЗ тварин 3 дефіцитом тиреоїдних гормонів, які піддавались поєднаному впливу ХС та ПФН, виявили значне погіршення показників гіпофізарно-тиреоїдного статусу відносно даних гіпотиреоїдних щурів.

Висновки. Отже, узагальнюючи викладене можна стверджувати, що помірне динамічне фізичне навантаження здійснює позитивний вплив на структурно-функціональний стан ЩЗ при дії тривалого емоційно-больового стресу, але такий ефект відсутній за умов гіпотиреоїдної дисфункції, що потребує подальших досліджень.

\section{References:}

1. Helmreich DL, Tylee D. Thyroid hormone regulation by stress and behavioral differences in adult male rats. Horm Behav. 2011; Jun, 12; 60(3):284-91. doi: 10.1016/j.yhbeh.2011.06.003.

2. Shields GS, Kuchenbecker SY, Pressman SD, Sumida KD, Slavich GM. Better cognitive control of emotional information is associated with reduced pro-inflammatory cytokine reactivity to emotional stress. Stress. 2016; Jun, 13; 19(1):63-8. doi: 10.3109/10253890.2015.1121983.

3. Lin X, Itoga CA, Taha S, Li MH, Chen R, Sami K, et al. C-Fos mapping of brain regions activated by multimodal and electric foot shock stress. Neurobiol Stress. 2018; Feb, 7; 8:92-102. doi: 10.1016/j.ynstr.2018.02.001. 4. Vadzyuk YuS. Optymizatsiya farmatsevtychnoho zabezpechennya khvorykh z patolohiyeyu shchytopodibnoyi zalozy [avtoreferat]. Lviv: Lviv. nats. med. un-t im. Danyla Halytskoho; 2017. P.28.

5. Uribe RM, Jaimes-Hoy L, Ramirez-Martinez C, Garcia-Vazquez A, Romeo F, Cisneros M, et al. Voluntary exercise adapts the hypothalamus-pituitary-thyroid axis in male rats. Endocrinology. 2014; Feb, 26; 155(5):202030. doi: 10.1210/en.2013-1724.

6. Akarachova ES, Kotova OV, Vershynina SV, Ryabokon IV. Stress i rasstroystva adaptatsii. Lyechaschiy vrach. 2014; Iyun, 18; 6:61-5. https://www.lvrach.ru/2014/06/15435991/

7. Directive 2010/63/EU of the European Parliament and of the Council of 22 September 2010 on the protection of animals used for scientific purposes. Official Journal of the European Union. 2010; L276:33-79.

8. Nebozhina MV. Vliyanie eksperimentalnogo gipotireoza, vyzvannogo vvedeniyem merkazolila na sostoyaniye protsessov svobodnoradikalnogo okisleniya $\mathrm{v}$ tkani pecheni $\mathrm{v}$ usloviyakh rentgenovskogo oblucheniya. Endokrynolohiya. 1999; 4(2):261.
9. Valov SD. Neyrobiologicheskiye aspekty regulyatsii proliferatsii, rosta i tsitodifferentsirovki zhelezistykh epiteliyev razlichnogo geneza [avtoreferat]. Tomsk: Sibir. gos. med. un-t; 2004. P.40.

10. Lysachenko OD. Zminy struktury miokarda peredserd pry fizychnykh navantazhennyakh ta $u$ vidnovlyuvalnomu periodi [avtoreferat]. Kyiv: Nats. med. un-t im. O.O. Bohomoltsya; 2002. P.19.

11. Detsyk OZ. Metodychni pidkhody do uzahalnennya rezultativ naukovykh doslidzhen. Galician medical journal. $2011 ; 18(2): 5-8$.

12. Herasymchuk MR, Popadynets OG, Pobigun NG. Morfofunktsionalni osoblyvosti shchytopodibnoyi zalozy pry eksperymentalnomu hipotyreozi ta fizychnomu navantazhenni. Eksperymentalna i klinichna medytsyna. 2016; 2(71):49-55.

13. Mishra N, Mishra VN, Devanshi. Exercise beyond menopause: Dos and Don'ts. J Midlife Health. 2011; Jul; 2(2):51-6. doi: 10.4103/0976-7800.92524.

\section{УДК 612.176+616-056.2+612.44+616.441-008.64 \\ ИССЛЕДОВАНИЕ ВЛИЯНИЯ ФИЗИЧЕСКОЙ НАГРУЗКИ И СТРЕССА НА СОСТОЯНИЕ ЩИ- ТОВИДНОЙ ЖЕЛЕЗЫ ПРИ ГИПОТИРЕОЗЕ}

\section{Н.Г. Побигун}

\author{
Ивано-Франковский нацииональный медицинский \\ университет, кафедра физиологии, \\ 2. Ивано-Франковск, Украина, \\ ORCID ID: 0000-0001-8367-3419, \\ e-mail: nadiia.pobigun@ukr.net
}

Резюме. Цель: изучение влияния хронического стресса (XC) и умеренной физической нагрузки (УФН) на изменения морфофункционального состояния щитовидной железы (ЩЖ) при гипотиреозе (Г).

Материалы и методы. 48 половозрелых крыс-самцов были разделены на 4 группы: 1-я - интактные; 2-я - животные с Г; 3-я - животные в условиях ХС и УФН; 4-я - животные с Г в условиях ХС и УФН. Г моделировали путем добавления к воде, которую пили животные, мерказолила в течении 15 дней. ХC моделировали по 1 часу в течении 30 дней. УФН моделировали бегом в тредбане в течении 30 дней. В плазме крови определяли концентрации тиреотропного гормона (ТТГ), трийодтиронина (сТ3), тироксина (сT4) и рассчитывали показатель тиреоидного индекса (ТИ). Морфологическое состояние ЩЖ изучали с помощью микроскопии. Статистический анализ полученных результатов проводили с использованием t-критерия Стьюдента. Отличия считали статистически вероятными при $\mathrm{p}<0,05$.

Результаты исследования. Сочетанное влияние ХС и УФН не привело к достоверным изменениям содержания ТТГ и йодсодержащих гормонов ЩЖ относительно результатов интактных животных. Данные микроскопического исследования ЩЖ подтверждают биохимические изменения и свидетельствуют об отсутствии негативного действия ХС на показатели тиреоидного профиля при УФН. Однако имуноферментный анализ плазмы крови и микроскопическое 
исследование ЩЖ животных с дефицитом тиреоидных гормонов в условиях ХС и УФН обнаружили значительное ухудшение показателей гипофизарнотиреоидного статуса относительно данных гипотиреоидных крыс.

Выводы. УФН осуществляет положительное влияние на структурно-функциональное состояние ЩЖ при действии ХC, но такой эффект отсутствует в условиях гипотиреоза.

Ключевые слова: хронический стресс, физическая нагрузка, гипотиреоз, тиреоидные гормоны, морфология щитовидной железы.

\section{UDC 612.176+616-056.2+612.44+616.441-008.64 INVESTIGATION OF PHYSICAL LOADING AND STRESS INFLUENCE ON THE STATE OF THY- ROID GLAND AT HYPOTHYROIDISM}

\section{N.G. Pobigun}

Ivano-Frankivsk National Medical University, physiology department, Ivano-Frankivsk, Ukraine, ORCID ID: 0000-0001-8367-3419, e-mail: nadiia.pobigun@ukr.net

Abstract. Relevance. The hormones of thyroid glands (TG) take part in regulation of practically all types of metabolic processes and activity of visceral systems of organism. The normal level of thyroid hormones is obligatory part of adaptive reactions. At scientific investigations of functional state of TG under action of stress opposite changes of level of thyroid hormones were determined. It can be explained by influence of different of character and duration stress factors. The acute stress causes mobilization of organism in result of increasing of level of thyroid hormones together with cateholamines and corticosteroids. The long-term stress leads to decreasing of secretory function of TG. Thus under conditions of stress there is progressive exhaustion of functional state of TG after activation at continued influence of stressful factors. Physical activity can be method of prevention of disease and increasing of functions of organism. The regular moderate physical loading leads to increasing of resistance of organism to influence of stressful factors. The changes of function of TG depend on duration and intensity of loading.

The aim of investigation is the study of combined influence of chronic emotional painful stress (CS) and moderate physical loading (MPL) on changes of morphological and functional state of thyroid gland at hypothyroidism $(\mathrm{H})$.

Materials and methods. Experiments were performed on 48 white laboratory sex matured male rats. Animals were divided on four groups: the fist - intact animals; the second - animals with $\mathrm{H}$; the third - animals in the conditions of influence of CS and MPL; the fourth - animals with $\mathrm{H}$ in the conditions of influence of CS and MPL. The $\mathrm{H}$ was modelled by everyday addition of mercazolilum (dose $10 \mathrm{mg} / \mathrm{kg}$ of body weight of animal) to drinking water during 15 days. The CS was modelled by 1 hour per day during 30 days. The MPL was modelled by running ( $15 \mathrm{~min}$ per day) in tread ban every day with velocity of tape $20 \mathrm{~m} / \mathrm{min}$ during 30 days. The functional activity of TG was estimated by the concentration of thyroid stimulating hormone of adenohypophysis (TSH), free triiodothyronine (fT3), free thyroxin (fT4) in blood plasma and calculation of thyroid index (TI) according to formula: $\mathrm{TI}=(\mathrm{fT} 3+\mathrm{fT} 4) / \mathrm{TSH}$. The morphological state of TG was studied by light and electron microscopy. The statistical analysis of results was processed using Student's test with Bonferroni-Holm correction in program Statistica 6.0. The differences were statistical significant at $\mathrm{p}<0,05$.

Results and their discussion. The combined influence of CS and MPL did not cause significant changes of contents of TSH and iodine-containing hormones of TG in blood plasma in comparison to results of intact animals. The data of microscopic investigation of TG of rats under specified conditions confirm biochemical changes and detect about absence of negative action of long-term stress on thyroid indexes at MPL. However, immune ferment analysis of blood plasma, light and electron microscopy of TG of animals with thyroid hormones deficiency under combined influence of CS and MPL caused to more substantial changes of indexes of pituitary-thyroid axis (significant increasing of level of TSH, decreasing of contents of fT3, fT4 and TI) in comparison to results of animals with $\mathrm{H}$.

Conclusions. The moderate dynamic physical loading causes positive influence on structural and functional states of TG under action of long-term emotional painful stress but this effect is absent in conditions of hypothyroid dysfunction.

Keywords: chronic stress, physical loading, hypothyroidism, thyroid hormones, morphology of thyroid gland. 